\title{
Building Library Collections in University Libraries in Nigeria
}

\section{G. T. Onadiran and R. W. Onadiran}

The purpose of this study was to examine building library collections in university libraries in Nigeria. Specifically, it investigated the number of books per student, annual growt h of library materials, type of selection policy, acquisition procedure, and the relationship between book dealers and the university libraries in Nigeria. The data was obtained through an inquiry form, visits, and discussions with acquisition librarians and the teaching staff.

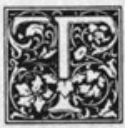

he Federal Republic of Nigeria is the most populous state in Africa. At the time of the 1963 census its population was $56,654,000$. The present population is not known, however, United Nations statistics suggest a figure in the region of 70 million. ${ }^{1}$

Since attaining independence from Great Britain in 1960, Nigeria has been steadily building on the educational foundations established during the previous hundred years by Western missionaries and the British colonial administration. In 1932, Yaba College, the first institution to provide higher education in Nigeria, was established by the British in response to demands of local leaders. However, the institution did little more than provide training for intermediate level civil service personnel. In 1948 the college became the nucleus of another higher educational institution, the university college, Ibadan.

On October 1, 1960, when Nigeria became politically independent, there was only one university in the country. Since then, the development of university education in Nigeria has been dramatic and rapid. Of the existing thirteen universities, one each was established in 1948 and
1960, three universities were established in 1962, one university was established in 1970 , and seven were established in $1975 .^{2}$

Within the last ten years university libraries have been forced by a number of factors to recognize the importance of adequate and relevant acquisitions of library materials. The most obvious of these factors is the growth in campus population and changes in its composition. For instance, in 1948 there were 210 students in the university college Ibadan, the only university college in the country. ${ }^{3}$ By the mid-1960s there were over 7,000 students enrolled in the five main universities in Nigeria. This figure steadily rose to 49,301 students in the thirteen Nigerian universities in October 1977-78; 5,787 of the 49,301 were enrolled in subdegree courses; 41,334 in courses leading to first degrees, and 2,180 for graduate study. The total number of teachers in the 1976-77 academic year was $4,195 .^{4}$

All the university libraries in Nigeria accept the need to make basic library provisions for their members. Readers are entitled to borrow the following number of books: academic staff and graduate students 20 and 10 books respectively, for four weeks; undergraduate students are

G. T. Onadiran is senior lecturer, and R. W. Onadiran is librarian, both at Ahmadu Bello University, Zaria, Nigeria. 
allowed 5 books for two weeks. Ten kobo (equivalent to \$.15) are paid for each day a book is overdue. If a book is lost, twice the price of the book must be paid by the offender.

While in most developed countries students and lecturers have many other libraries they may use, in addition to their university library, in Nigeria, students, lecturers, and scholars are hampered by the scarcity of bookshops and other libraries $^{5}$ as well as vast distances between the existing few. In such a situation the need for abundant, relevant, and large quality collections of library materials cannot be overemphasized. The purpose of this study is to examine acquisitions of library materials in university libraries in Nigeria. Specifically, the study will provide answers to the following questions:

1. What is the selection policy of library materials in university libraries in Nigeria?

2. To what extent do the faculty and staff participate in book selection in university libraries in Nigeria?

3. What is the acquisition procedure in university libraries in Nigeria?

4. What is the relationship between book dealers and university libraries in $\mathrm{Ni}$ geria?

\section{REVIEW OF THE LITERATURE}

A good deal has been written and spoken in the last decade or two by Western librarians about the problems and difficulties faced by libraries attempting to select and acquire publications from developing nations. Such factors as the undeveloped state-of-the-book trade in certain countries, foreign currency restrictions, and lack of bibliographical control have all created problems for Western librarians. These problems have been overcome or minimized in a variety of ways. There is a remarkable lack of reciprocal effort on the part of librarians in the developing countries, both at the global level and within the individual countries. In order to evaluate various types of selection programs, one needs to secure hard data, not opinions. To date little evidence is available with which one may describe objectively the acquisitions of library materials in university libraries in Nigeria. Ombu's work ${ }^{6}$ was based on his experience in two universities in Nigeria. Similarly, Jegede ${ }^{7}$ and Onuorah ${ }^{8}$ based their works on their experiences in the University of Lagos and Nigerian Institute of Social and Economic Research, Ibadan, respectively. Little attention has been paid to building of library materials in Nigeria by way of study, research, and publication. For instance, all the issues of Nigerian Libraries (the only library journal in Nigeria) from volume 1, number 1, February 1964 to volume 8, number 1, April 1972 contain 120 articles. Of these, only three, or 2.5 percent, deal with acquisitions. ${ }^{9}$ An attempt is made in this paper toward remedying this situation.

\section{PROCEDURE}

An examination of library literature provided some information as to the pattern being followed in the building of library materials. It seemed, however, that the most pragmatic answers to building of library materials could be obtained from libraries involved in the day-to-day solutions of building library materials. Toward this end, a questionnaire was designed and sent to all thirteen functioning universities in Nigeria. The questionnaire sought to discover selection policy, faculty participation in book selection, acquisition procedure, and the relationship between book dealers and the university libraries in Nigeria. In addition, the investigators held discussions with some of the teaching staff and book dealers on building library materials. Eleven of the thirteen university libraries contacted replied. Universities of Ilorin and Sokoto (both recently established) did not respond to the inquiry forms.

\section{RESULTS AND DISCUSSIONS Library Stock}

An essential component of the university library is the information housed there. A variety of up-to-date materials in various formats, carefully selected, is needed to meet the curriculum and interest needs of the students and faculty members. The decisions concerning amounts of materials, formats, and quantities of supporting equipment should be 
made on the basis of programs and user needs. Clapp and Jordan listed the following criteria as a measure for adequacy of academic library collections:

1. The student body-size, composition (graduate or undergraduate), scholastic aptitude, socioeconomic, and intellectual background.

2. The faculty-size, involvement in research, etc.

3. The curriculum-number of courses, proportion of laboratory to literature courses, etc.

4. Methods of instruction-extent and use of textbook readings assigned, and independent study.

5. Availability of suitable places for study on the campus.

6. Geography of the campus-proximity to other large libraries.

7. The intellectual climate-study inducements and distractions. ${ }^{10}$

The present strength of the stock is presented in table 1 . Three university libraries, or 27.3 percent have 30 or more books per student. The university of Ibadan, the oldest university in Nigeria, possesses one of the best collections in medicine, agriculture, and the social sciences. It has grown rapidly and its activities before the creation of the National Library in 1964 include acting as a legal depository center for Nigeria, issuing a Nigeria bibliography, ${ }^{11}$ and a subject catalog of its collection.

Universities of Nsukka, Zaria, Ife, and
Lagos (all established between 1960 and 1962) have not been improving their library materials as they should. For example, in 1967 it was reported that Zaria and Nsukka had 27,000 and 21,300 books respectively. ${ }^{12}$ After two or more decades of establishment, none of these older universities has 30 or more books per student. The effectiveness of the university library services depends on materials being made available for use when needed. ${ }^{13}$ The university library must contain not only abundant, quality books, but also periodicals, newspapers, filmstrips, tapes, and records.

Although the universities in Nigeria come under the supervision of Nigerian University Commission for finance, there is no real cooperation between libraries. At present no official statement of general standards for university libraries has been made by either the Nigerian Library Association or the Nigerian University Commission. It would appear that a statement is needed. In some instances the planning of the academic programs of universities has been done with little or no reference to the book and journal requirements of the programs created. New departments have been initiated and later the discovery has been made that library implications have not been taken into consideration, and that no lead time for assembling the printed materials has been allowed. The librarian has been called in too late. Therefore, standards or guidelines for comput-

TABLE 1

NIGERIAN UNIVERSITY LIBRARIES: BOOKS PER STUDENT IN 1979-80 SESSION

\begin{tabular}{lccrc}
\hline \hline Universities & $\begin{array}{c}\text { Year } \\
\text { Established* }\end{array}$ & $\begin{array}{c}\text { Registered } \\
\text { Students }\end{array}$ & $\begin{array}{c}\text { Volume of } \\
\text { Books in } \\
\text { Main Library }\end{array}$ & $\begin{array}{c}\text { Volume of } \\
\text { Books Per } \\
\text { Student }\end{array}$ \\
\hline Jos Nsukka & 1975 & 2,700 & 41,223 & 15.27 \\
Bayero & 1960 & 6,500 & 155,000 & 23.85 \\
Ife & 1962 & 2,318 & 75,000 & 32.36 \\
Calabar & 1961 & 10,000 & 275,000 & 27.50 \\
Port Harcourt & 1975 & 2,243 & 47,000 & 20.95 \\
Benin & 1975 & 1,400 & 21,000 & 15.00 \\
Zaria & 1970 & 2,000 & 65,501 & 32.75 \\
Ibadan & 1962 & 8,500 & 237,466 & 27.93 \\
Lagos & 1948 & 5,651 & 350,000 & 61.94 \\
Maiduguri & 1962 & 10,000 & 202,539 & 20.25 \\
$\quad$ Total & 1975 & 2,000 & 50,000 & 25.00 \\
\hline
\end{tabular}

\footnotetext{
*Year established refers to the year the university started as postsecondary institution.
} 
ing the various factors in book collection building, as related to curricular and research programs, are needed. For the time being the Nigerian University Commission may create a committee of experts to advise the universities and the commission on matters relating to library collections and services and to take its recommendations as a criterion for the allocation of grants for the universities to support the library programs.

\section{Volumes of Books Added from 1976-77 to 1978-79 Session}

The majority of students and teaching staff in Nigerian universities cannot afford to build personal libraries and they expect the university library to supply their book and journal needs. In such a situation, regular purchase of library books and other learning aids cannot be overemphasized.

Table 2 shows the growth of library collections in the past three years. While acquisition of library materials in part depended upon the rate at which new publications appear, there are obviously great differences in the growth of library materials among universities. The older universities of Ibadan, Ife, Zaria, Nsukka, and Lagos have very low growth rates. The 1976-77 year was good for acquisitions for all libraries in the study. The number of monographs rose by more than 1,500 - an 8.3 percent increase over the entire collection.

Since the $1977-78$ session, when the federal government of Nigeria introduced free universal primary education, the funds allocated to the universities have been on the decrease. Libraries are in competition with other more popular items in the budget, such as teaching staff salaries. Consequently, library book growth has been greatly affected. In the opinion of the writers, the primary obligation of any university library is to provide the materials which now and in the future best contribute to the fulfillment of the functions of the institutions. If the Nigerian government kept on denying the universities enough funds, how would this be achieved? What is worth doing at all, is worth doing well.

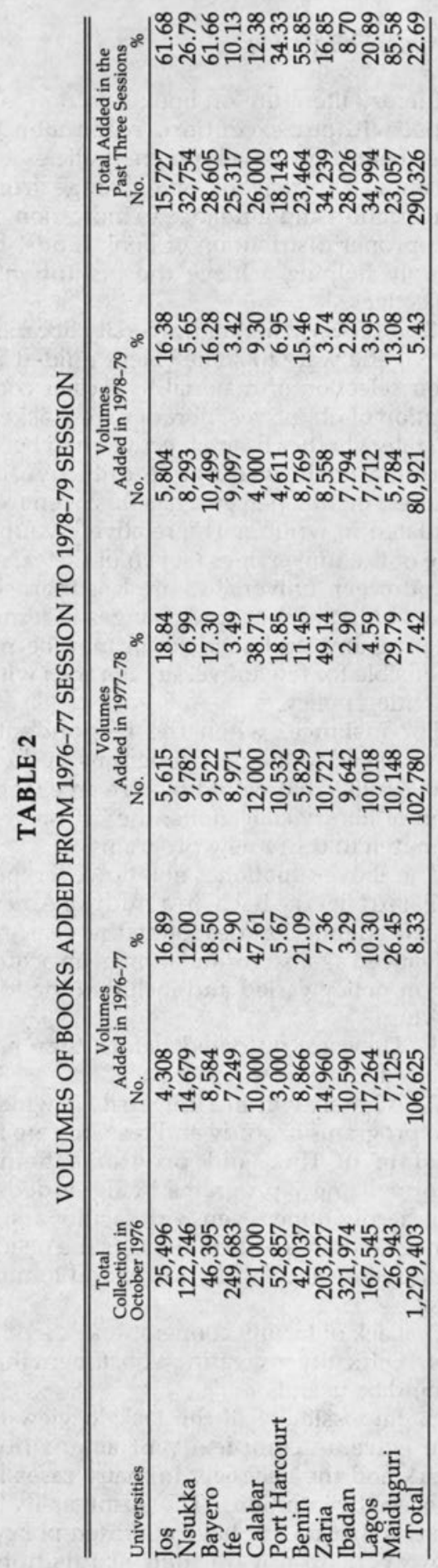




\section{Acquisition Policy}

Library literature on book selection, almost without exception, recommends that collection development policies be written. The reasons given range from clarification and guidance to indication of the proper distribution of book funds, to simply helping achieve the institution's objectives.

To discover whether university libraries in Nigeria were to some extent guided in their selection of material by a clear conception of objectives, libraries were asked to state whether their objectives had been formulated in writing. In only two libraries, or 18.2 percent, has this been formulated in writing. The relatively young age of the universities (seven of the existing thirteen universities are less than six years old) and the rapid changes in terms of programs and curriculum may be responsible for few university libraries with a written policy.

For instance, when the respondents were asked to list new programs in their universities that would require an expansion of library collections, the list ranged from ten to thirty new programs.

The above situation is not, however, peculiar to Nigeria. Bach, in a study of American academic libraries found that reasons advanced against formulation of an acquisition policy varied and included the following:

1. They are outdated before they are drafted.

2. A library within a university in which the programs of study and research are in a state of flux-old programs being dropped, new programs being addedcan hardly hope, even with faculty assistance, to draft a code that meets the needs of students and faculty today and tomorrow.

3. Lack of faculty cooperation.

4. Difficulty in creating a document that would be useful.

5. Impossibility of the task in view of the extreme complexity of acquisition work and the necessity in many cases to proceed by intuition. ${ }^{15}$ Those university libraries that do not have a written policy, however, do not do their acquisitions work merely by what people say, since written guidelines have been developed and memorized based on the curricula of the institution served. Written acquisition policy is a necessity in these days of tighter budgets and inflation.

\section{Faculty Participation}

The selection of library materials is probably the most important and one of the most difficult activities of a livrary. This is so because the book purchased should be the best of its kind available. Those who do the selection should individually, or as a group, have advanced knowledge of the subject matter and access to all kinds of bibliographic data. They should have an intimate and personal knowledge of the existing collections in their fields. From the authors' experiences, neither the librarian nor teaching staff can rightfully claim to meet fully all of the above criteria.

In a study of building library collections in university libraries in Nigeria, librarians were asked to indicate the extent of university community participation in book selection. It is sad to note the low participation in book selection by the university community, particularly the teaching staff. In three libraries, ( 27 percent) faculty members actively participate. In another three libraries (27 percent) faculty members participate moderately in book selection. From the authors' experiences and observations, the reasons for low teaching staff participation are similar to some of the findings in the United States which indicated that:

1. The teaching staff is already overburdened with other duties.

2. Some of the teaching staff lack familiarity with the world of books.

3. Some of the teaching staff do not care (the text book is enough).

4. A few staff members suffer from a constitutional inclination toward laziness. ${ }^{16}$

It is unfortunate to note the low participation of other professional librarians outside the acquisitions department in the selection of library materials. This condition is most common in Nigeria where there is an acute shortage of professionally qualified librarians. Until recently, professional 
training was usually obtained through the prevailing British pattern of preprofessional recruitment, followed by in-service study for the examinations of the British Library Association leading to the Associationship (ALA) or Fellowship (FLA) of the Association. In fact, the establishment of a library school was not on the priority list until the early 1960s. Today, there are four library schools in Nigeria-Ibadan, Zaria, Maiduguri, and Bayero, established in 1960, 1968, 1976, and 1978, respectively. All the library schools (with the exception of Ibadan) offer a library science program at the undergraduate level. In such a situation there is need for fully exploiting the considerable range of university expertise.

\section{Procedures Used in Informing Teaching Staff of New Publications}

In a study of acquisition procedures in university libraries in Nigeria, the librarians were asked to indicate procedures used in informing academic staff of new publications. It is interesting to note that many libraries send review cards (90.9 percent) and circulars or letters (63.6 percent) to the teaching staff. This result must be noted with caution. In 1976 at the University of Lagos library, it was discovered that 77 percent of the titles sent were recommended for purchase by the teaching staff. ${ }^{17}$ This is in contrast to the low level of teaching staff participation in book selection found in this study. Certainly, it is a big problem to solicit the cooperation of the teaching staff and a still bigger problem to keep up their interest in recommending titles to the library for purchase. While we should not expect the teaching staff to do the work of selection of library materials without aid, full benefit of the special knowledge residing with its members should be taken advantage of, and every effort should be made to persuade its members to suggest freely titles for purchase.

\section{Sources of Books Acquired}

The acquisitions policy of a university library is determined mainly by the academic program of the university itself. One, therefore, expects to find on its shelves books and journals that will meet the needs of undergraduates, lecturers, and research workers. Library materials must therefore be acquired in one of three ways: (a) by purchase, (b) by gift and, (c) by exchange. Regardless of the source from which a material is obtained, the efficiency of acquisitions work can be measured mostly by the quickness with which the desired publications are obtained and made available to the users of the library. An important factor that influences efficiency is the selection of the right source of supply.

It is interesting to note the source(s) of books acquired in university libraries in Nigeria (table 3 ). In all the libraries, the bulk of the library materials are from foreign countries like the United States, Britain, and those in Western Europe. As high

TABLE 3

SOURCES OF BOOKS ACQUIRED IN 1978-79 SESSION

\begin{tabular}{|c|c|c|c|c|c|c|}
\hline \multirow[b]{3}{*}{ Universities } & \multirow{3}{*}{$\begin{array}{l}\text { Current } \\
\text { Serials }\end{array}$} & \multirow{3}{*}{$\begin{array}{c}\text { Total Books } \\
\text { Acquired in } \\
1978-79 \\
\text { Session }\end{array}$} & \multicolumn{4}{|c|}{ Sources of Books Acquired } \\
\hline & & & \multicolumn{2}{|c|}{ Local Dealer } & \multicolumn{2}{|c|}{ Foreign Dealer } \\
\hline & & & No. & $\%$ & No. & $\%$ \\
\hline Jos & 1,200 & 5,804 & 290 & 5.0 & 5,514 & 95.0 \\
\hline Nsukka & 1,804 & 8,293 & 207 & 25.0 & 6,220 & 75.0 \\
\hline Bayero & 1,061 & 10,499 & 1,050 & 10.0 & 9,449 & 90.0 \\
\hline Ife & 4,500 & 9,097 & 1,819 & 20.0 & 7,278 & 80.0 \\
\hline Calabar & 1,200 & 4,000 & 40 & 1.0 & 3,960 & 99.0 \\
\hline Port Harcourt & 1,176 & 4,611 & 1,383 & 30.0 & 3,228 & 81.8 \\
\hline Benin & 3,218 & 8,769 & 1,596 & 18.2 & 7,173 & 18.8 \\
\hline Zaria & 3,155 & 8,558 & 1,284 & 15.0 & 7,274 & 85.0 \\
\hline Ibadan & 4,920 & 7,794 & 1,559 & 20.0 & 6,235 & 80.0 \\
\hline Lagos & 4,780 & 7,712 & 1,697 & 22.0 & 6,015 & 78.0 \\
\hline Maiduguri & 1,168 & 5,784 & 1,157 & 20.0 & 4,627 & 80.0 \\
\hline Total & 28,182 & 80,921 & 13,948 & 17.24 & 66,973 & 82.76 \\
\hline
\end{tabular}


as 99.0 percent of the library materials in the university of Calabar are imported from foreign countries. This result is similar to Enu's observation that the majority of the books in the country are published abroad. ${ }^{18}$ Indigenous activity is underdeveloped in the publishing and printing industries and also in the writing of books. Even where some form of organized publishing exists, the field is heavily dominated by foreign concerns. Opinions have differed about this fact. For example Beng, ${ }^{19}$ an expatriate, was of the opinion that the localization of foreign firms has benefited Nigeria to a large extent. Oth$\mathrm{ers}^{20}$ have claimed that with regard to educational books (the bulk of their output) they have helped to impede the growth of indigenous publishing industries. In fact, Oniboje, a Nigerian publisher, complained that foreign publishers' attitudes towards the indigenous publisher "varies from open ridicule and patronizing tolerance to outright threats and open hostility. ${ }^{\prime 21}$ The fact of the matter is that Nigerian publishers cannot compete effectively with foreign based firms due to lack of skilled manpower and technical difficulties, particularly with printing machines and maintenance. It is a cruel irony that the "book revolution" that has occurred in the past decades, with all that it offers in the way of intellectual, cultural, and technical enrichment, has failed to penetrate the very regions where it could be utilized for the general uplifting of the people. Advances in printing and distribution techniques have made it possible to produce books on a scale that has transformed publishing into a mass communication industry. The problem is to bring these techniques to those regions most in need.

In present-day Nigeria, the lack of indigenous and active publishing companies also means that there is lack of sufficiently organized book trade within the country. In fact, there is no book trade journal like the Publishers Weekly. In addition, there are no national bibliographies for current and retrospective materials published in Nigeria. The National Bibliography of Nigeria, published by the National Library, is irregular. Consequently, university libraries resort to the use of overseas agents, through whom books are purchased.

\section{Length of Delivery Time}

Not all books are urgently needed. On the other hand, the time when a book is most likely to be most useful is the period immediately following the decision to buy it.

The needs of any library's users are easily stated. They usually want a particular book when it is being reviewed, talked about, displayed in bookstore windows. Metcher and Soul are of the opinion that any library which cannot provide this month's book is a backward library. ${ }^{22}$ This may be impossible in the developing country such as Nigeria; all the same, one would expect a reasonable time of delivery for any book ordered either from local or foreign agents. An examination of the time it takes to receive book orders from local and foreign dealers indicates that, on the average, it takes three to six months to receive books. The result is not surprising, because from experience it takes about six to nine weeks between the actual posting date from England and the receipt of the book in Lagos. Book consignments from dealers are usually sent by surface mail which further slows the procedure and even jeopardizes delivery. It is not surprising that some books take ten to twelve months before delivery.

Local book dealers are equally slow in delivering library materials. This is because many of the titles required by a university library are unlikely to be stocked by the typical Nigerian bookseller. The bookseller is a businessman who has to concern himself with cash flow and the utilization of his assets, particularly shelf space.

\section{Problems Encountered by Libraries and Book Dealers}

The importance of acquisitions evaluating its firm order supplies is mentioned from time to time in the literature of library science. ${ }^{23}$ It is generally agreed that before an order goes to any book dealer it is necessary to establish a trade agreement on delivery price, discounts, speed of delivery, invoice documentation, reports on or- 
ders, cancellations, etc. Like a businessman, the acquisition librarian is expected to bargain for the best terms for his library. It is necessary to insist on adherence to the terms and also press for high standards of service by rejecting unsigned invoices, by returning dirty and imperfect books, and by requiring reports on orders. This is even more necessary today due to cuts in academic spending combined with the increase in the price of books.

The problem of having many relevant books out of stock seems to be the most common experience from the local book dealers. Similarly, there is no difference between speed of delivery by local or foreign dealers. The bookshops in Nigeria are "a one-man-business." Their capital is meager with limited stock. The fact of the matter is, Nigerian bookshops and libraries are far from the book producing centers of the world and have to depend to a large extent on foreign book dealers and publishers.

In a study of the relationship between book dealers and university libraries in $\mathrm{Ni}$ geria, librarians were asked to indicate to what extent they encounter out of print, out of stock, and invoice documentation problems. The most serious problem was invoice documentation ( 46 and 36 percent with local and foreign dealers, respectively). The result is understandable, because local dealers lack staff and their accounting system is very poor. It is not uncommon to receive several letters on a bill that has been settled. The next problem is the frequency of out of stock ( 46 and 27 percent). If the local dealers could put their resources together and form big companies some of these problems may be reduced.

There is no difference between local and foreign book dealers in the problems of discount rates ( 36 percent each). This is very surprising. It is surprising because the law in Nigeria states that books should be sold at publishers' prices. Libraries, however, are normally entitled to a $10-15$ percent discount. The results, therefore, indicate that book dealers, both local and foreign, do not give libraries a rebate. From the writers' experience and discussions with book dealers, the book dealers are of the opinion that such discounts are used to defray the cost of shipping and other incidental expenses. Some of the local dealers, in many cases, increase the prices.

The acquisitions librarians complained about government restrictions on foreign exchange, which in their opinion slows down acquisitions work. On the other hand, local book dealers complained of the inability of the university libraries to settle their bills promptly. The foreign book dealers always insist that money must accompany each order.

\section{SUMMARY, CONCLUSIONS, AND RECOMMENDATIONS}

The general purpose of this study was to examine building library collections in university libraries in Nigeria. Specifically, it investigated the number of books per student, annual growth of library materials, type of selection policy, acquisition procedure, and the relationship between book dealers and the university libraries in Nigeria.

Data relating to building library materials were collected through the use of an inquiry form. Discussions were held with acquisitions librarians and book dealers. A total of eleven completed inquiry blanks were received, representing 84.6 percent of the Nigerian universities.

Three universities, or 27.3 percent, have 30 or more books per student. The national average of all universities is $28.5 \mathrm{vol}$ umes of books per student. Faculty participation in book selection is low in all the universities. In only two libraries, or $\mathbf{1 8 . 2}$ percent, has the selection policy been formulated in writing. In all the libraries, $\mathbf{8 0 . 0}$ percent or more of the books are imported from foreign countries and on the average it takes three to six months to receive book orders from foreign and local dealers. The frequency of out of stock books seems to be the most common problem experienced from local dealers.

From the analysis of data above, the following conclusions may be drawn.

Quality education is impossible without a quality library. There is need for all the libraries to increase their collections substantially. The decisions concerning 
amount of materials should be made on the basis of programs. The present annual growth of less than 10 percent is too low to produce quality education as desired by the people, states, and federal government! The writers recommend an annual growth in book collections of 50 percent for each of the new universities and 25 percent for the older universities for the next ten years.

The present system of selection largely by acquisition librarians cannot produce the quality of collections needed. There is need for more input by faculty members in book selection. A practical alternative might be centralized selection on a national basis. The Nigerian University Commission would manage the program and would hire subject specialists (60 individuals with backgrounds in different disciplines should be able to ensure good coverage) who would examine all new books currently being published and who would decide which books were appropriate for the undergraduate and graduate level. The 60 specialists would select 750,000 volumes per year. It will enable all the universities to have a comprehensive collection of books and periodicals covering all the subjects taught in the university.

The Nigerian government should remove books from the list of items that are subject to stringent exchange controls. There should also be a council whose sole responsibility will be to promote the writing, publishing, and the distribution of books. The objectives of the council should include:

1. to serve as the spokesman for the book industries in questions of finance, taxation, customs regulations, etc.

2. to promote, assist, and, where necessary, coordinate plans for concerted action on such questions as the training of personnel.

3. to provide information related to the book trade and practice which can serve the development of books and reading generally.

\section{REFERENCES}

1. Year Book of the Commonwealth (London: Her Majesty's Stationery Office, 1977), p.358-71.

2. Guide to Education and Training Resources in the Developing Countries of the Commonwealth-A Selection of Post-Secondary Courses and Institutions. (London: Commonwealth Secretariat, 1977), p.254-62.

3. A. Babs Fafunwa, The Universities of Nigeria in Commonwealth Universities Yearbook, Hugh W. Springer and T. Craig, eds., (Edinburgh, R. R. Clark, Ltd., 1976), p.1773-1825.

4. Commonwealth Universities Yearbook (Edinburgh: R. R. Clark, Ltd., 1979), p.1861-1829.

5. G. T. Onadiran and R. W. Onadiran, "Users of Public Library Services in Nigeria," Indian Librarian V.35(1):27-48 (June 1980).

6. Jigekuma A. Ombu, "Acquisition problems in Developing Countries," International Library Review V.9(1):83-93 (Jan. 1977).

7. O. Jegede, "Problems of Acquisitions of Library Materials in a Developing Country: University of Lagos Library Experience," International Library Review V.9(2):291-99 (Apr. 1977).

8. Regina U. Onuorah, "Acquisitions of Government Publications in Nigeria," Special Libraries V.67(12):585-88 (1976).

9. Briggs C. Nzotta, "Written Acquisitions policies in Public Libraries in Nigeria," Nigerian Libraries V. $9(1 \times 2): 83-89$ (Apr. and Aug. 1973).

10. Vernor W. Clapp and Robert T. Jordan, "Quantitative Criteria for Adequacy of Academic Library Collections," College \& Research Libraries V.26(5):376-80 (Sept. 1965).

11. Cosmas E. Enu, "Problems of Nigerian University Libraries," Unesco Bulletin for Libraries V.27(2):84-91 (Mar.-Apr. 1973).

12. W. J. Plumbe, "Ahmadu Bello University Libraries: The First Three Years," Nigerian Libraries V.3(2):46-62 (Aug. 1967) and Dorothy S. Obi, "The University of Nigeria Libraries: A Preliminary Survey of Their Development and Resources. Nigerian Libraries V.3(2):69-74 (Aug. 1967).

13. G. T. Onadiran and R. W. Current, "Problems in School Library Development in Developing Nations," The School Librarian V.28(1):14-17 (Mar. 1980).

14. Marion L. Buzzard, "Writing a Collection Development for an Academic Library," Collection Management V.2 (4):317-28 (Winter 1978). Rutherford D. Rogers and David C. Weber, University Library 
Administration (New York: Wilson 1971), p.114-45 and Stephen Ford, The Acquisition of Library Materials (Chicago: American Library Assn., 1973), p.1-2.

15. Harr Bach, "Acquisition Policy in the American Academic Library," College \& Research Libraries 18(6): 442 (1957).

16. See George M. Jenks, "Book Selection: An Approach for Small and Medium-sized Libraries," College \& Research Libraries V.33(1):28-30 (1972). Virgil F. Massmas, and David R. Oslan, "Book Selection: A National Plan for Small Academic Libraries," College \& Research Libraries V.32(4):271-79 (July 1971).

17. Jegede, "Problems of Acquisitions," p.291-99.

18. Enu, "Problems of Nigerian University Libraries," p.84-91.

19. Ronald Charles Benge, Cultural Crisis and Libraries in the Third World (London: Clive Bingley, 1979), p.167-71.

20. S. B. Bandara, "Provision of Periodicals in the Libraries of Sri Lanka," International Library Review (7):15-28 (1975).

21. G. O. Oniboje, "Wanted: A Cultural Revolution, Not a Dialogue" in E. Oluwasanmi, and others (eds.), Publishing in Africa in the Seventies (lle-Ife, Nigeria: University of Ife Press, 1975), p. 268.

22. Daniel Metcher and Margaret Saul, Metcher on Acquisition (Chicago: American Library Assn., 1961), p.169.

23. See Stephen Ford, The Acquisition of Library Materials (Chicago: American Library Assn., 1973), p.62. Guy R. Lyle, The Administration of the College Library, (4th ed.; New York: Wilson, 1974), p.186-87, and Norman Higham, The Library in the University: Observations on a Service (London: Andre Deutsch Ltd., 1980), p.46. 